\title{
Geographic Area
}

National Cancer Institute

\section{Source}

National Cancer Institute. Geographic Area. NCI Thesaurus. Code C16632.

Any demarcated area of the Earth; may be determined by both natural and human boundaries. 